\title{
Factors associated with mechanical restraint in the hospital environment: a cross-sectional study*
}

\section{Fatores associados à contenção mecânica no ambiente hospitalar: estudo transversal Factores asociados con la contención mecánica en el entorno hospitalario: estudio transversal}

How to cite this article:

Souza LMS, Santana RF, Capeletto CSG, Menezes AK, Delvalle R. Factors associated with mechanical restraint in the hospital environment: a crosssectional study. Rev Esc Enferm USP. 2019;53:e03473. DOI: http://dx.doi.org/10.1590/S1980-220X2018007303473

\section{Lívia Maria da Silva Souza ${ }^{1}$ Rosimere Ferreira Santana ${ }^{1}$ \\ Cristiane da Silva Gabriel Capeletto ${ }^{1}$}

D Arianna Kassiadou Menezes ${ }^{1}$

Domulo Delvalle ${ }^{1}$

* Extracted from the dissertation: "Contenção mecânica no ambiente hospitalar: estudo transversal”, Mestrado Profissional em Enfermagem Assistencial, Universidade Federal Fluminense, 2018.

1 Universidade Federal Fluminense, Escola de Enfermagem Aurora de Afonso Costa, Niterói, RJ, Brazil.
Corresponding author:

Bruna Karen Cavalcante Fernandes

Travessa Michele, 30, Passaré

CEP 60861-444 - Fortaleza, CE, Brazil

brunacavalcanteff@gmail.com

\begin{abstract}
Objective: To estimate the prevalence of mechanical restraint in the hospital environment and the factors associated with its performance. Method: A cross-sectional, observational study with patients from a public hospital from the medical clinic, surgical clinic and intensive care unit evaluated by descriptive, univariate and multivariate analyses. Results: One hundred eleven (111) patients participated in the study. The prevalence of mechanical restraint was $51.4 \%$; bilateral rails on the bed were used in $100 \%$ of the restraints, and bilateral wrist restraints were also observed in $29.8 \%$. The most common justifications were the risk of falls $(100.0 \%)$ and the risk of non-scheduled removal of invasive devices (57.9\%). The restrained patients differ significantly from those not restrained by the following associated factors: male gender; age; stroke diagnosis; the hospitalization unit; ambulation capacity; the use of sedative medication; and the use of invasive devices. Conclusion: This study estimated a high mechanical restraint prevalence in the hospital environment and determined factors associated with the risk of a patient being restrained. A medical restraint evaluation team is recommended for an in-depth analysis of indication and therapy.
\end{abstract}

\section{DESCRIPTORS}

Restraint, Physical; Hospital Care; Nursing Care; Humanization of Assistance; Patient Safety. 


\section{INTRODUCTION}

Mechanical restraint is often used in health services as a way to control agitated, confused, and/or disoriented patients who are at risk of falling or who attempt to remove biomedical devices indicated for their treatment ${ }^{(1)}$. However, there are controversies and criticisms relevant to their practice $^{(2)}$.

In this study, it was decided to consider mechanical restraint as the use of devices and equipment attached or adjacent to the individual's body which limits or impedes movement, free movement to a position of choice, or access to the body itself, and which cannot be easily controlled or removed by the individual ${ }^{(3)}$.

Mechanical restraints may be considered: limb restraint by the use of straps or specific industrialized devices; the use of bilateral rails on the bed; belts to restrict mobility of the trunk or pelvis; vests used for an individual to remain attached to the bed or chair; or tables fixed to chairs which prevent the person from getting up. It is important to distinguish that procedures implemented during mobilization and/or displacement maneuvers in emergencies or necessary for the performing complementary exams or surgeries are not considered mechanical restraint. Therefore, the restraint does not include orthopedically prescribed immobilization devices or orthoses used for correction or postural support, among others.

Likewise, mechanical restraint does not refer to the possibility of physically securing a patient temporarily in order to perform viable examinations, clinical-surgical procedures or motor maneuvers in a more secure situation ${ }^{(1)}$. These actions imply expected benefits to the patient, facilitating the conditions for their health and integrity, unlike the use of restraint implemented from common sense or with the intention of reducing a hypothetical or improperly assessed risk.

Mechanical restraint has historically been used in health services in an indiscriminate and non-reflective manner. However, the literature shows that this practice is implemented in association with complications which are common to immobilization such as pressure injuries, pneumonia or deep venous thrombosis, and to events of greater severity directly related to restraint, including death due to severe trauma or suffocation. Forced immobilization also causes psychological stress and has a negative impact on cognitive abilities ${ }^{(4)}$.

Due to the possible adverse events related to the use of mechanical restraint, the Federal Nursing Council (COFEN) published Resolution 427 in 2012 to standardize nursing procedures for implementing mechanical restraint of patients ${ }^{(5)}$. This resolution corroborates what the Joint Commission advocates in its Non-violent Crisis Intervention Handbook, published in 2009. Both guide the use of mechanical restraint only when it is medically justified and the only means available to prevent immediate or imminent harm to the patient or others ${ }^{(6)}$; it also recommends an assessment of the patient every 1 hour and clinical monitoring of the level of consciousness, vital data, skin conditions and circulation in the patient's restrained sites and limbs, emphasizing special care for older adults and children. In addition, the Joint Commission emphasizes the need to train personnel to perform mechanical restraint, as well as the need to notify cases of death which may be associated with its use ${ }^{(5-6)}$.

In Brazil, the scientific production on mechanical restraint, its prevalence and associated factors is scarce. Thus, the objective of this study is to estimate the prevalence of mechanical restraint in the hospital environment and the factors associated with its performance.

\section{METHOD}

\section{STUDY DESIGN}

This is a quantitative cross-sectional study.

\section{SCENARIO}

The study population came from a public hospital of medium size financed by the Unified Health System, situated in a municipality of the Baixada Litorânea mesoregion, interior of the state of Rio de Janeiro, located $170 \mathrm{~km}$ from the capital city of Rio de Janeiro.

\section{SAMPLE DEFINITION}

The sample was defined as the total number of patients attended at the institution in the 8-month period. The hospital registered 489 hospitalizations in the adult hospitalization sectors from January to August 2016, according to data from the Department of Informatics of the Unified Health System (DATASUS). A sample was taken from this total to obtain the results of interest due to the impossibility of interviewing the entire population. As the main objective of the study was to estimate a $\mathrm{P}$ prevalence, the minimum sample size $(n)$ for a maximum overall error margin, corrected for population size, was defined by the formula:

$$
n=\frac{z_{\alpha / 2}^{2} N p(1-p)}{(N-1) e^{2}+z_{\alpha / 2}^{2} p(1-p)}
$$

In which, $z_{\alpha / 2}$ refers to the value of the random variable with standard normal distribution, for which the cumulative distribution function value is equal to $(1-\alpha) / 2(\alpha=$ the desired confidence level). Thus, the value of $z$ is closely related to the desired confidence interval for the proportions of interest. In the present case we used a $95 \%$ confidence interval, whose value corresponding to this area in the normal curve is 1.96; $p$ is the preliminary estimate of the prevalence of interest $\mathrm{P}$ and $e$ refers to the resulting overall margin of error (in this case a maximum overall error margin of $5 \%=0.05$ is desired). Due to the preliminary insufficiency in estimation for $\mathrm{P}$ and for the other proportions to be estimated in the study, the product $p(1-p)$ is substituted by its maximum value: 0.25 .

Thus, the minimum study sample size $(n)$ estimated for this study was 106 patients (restrained and not restrained). 


\section{SELECTION CRITERIA}

The selection criteria were: adults and older adults from the medical clinic, surgical clinic and intensive care units. Exclusion criteria were: emergency unit patients due to small number of beds and distinction from other scenarios.

\section{Data collection}

Data were collected from June 28 to November 28, 2017, out of a total of 111 participants. The visits happened three times a week on alternate days and times, and were carried out by a single researcher. Data collection took place in the morning and afternoon shifts, with each visit lasting approximately 4 hours and was conducted based on the patient's evaluation and completion of the Mechanical Restraint Use Observation Instrument, in which it was possible to obtain identification information of each participant, if they were restrained, what type of restraint was used, the date, hospitalization unit, and the number of nursing professionals present. In addition, data such as the admission date, medical diagnosis, use of medications, use of mechanical ventilation and invasive devices were also collected from the patient medical records. Data of restraint usage time and reasons cited by the team for using the restraint were collected through direct observation and the description in the medical record. When there were no reports in the medical records, the nurse was interviewed by direct interview following the observation form. The Richmond scales of agitation and sedation ${ }^{(7)}$, the Mini Mental State Exam ${ }^{(8)}$, the KATZ Daily Life Activity Scale ${ }^{(9)}$, and the presence and characteristics of pressure injury were performed directly in an interview with the patient and family.

\section{DATA ANALYSIS AND PROCESSING}

Data were analyzed using descriptive, uni and multivariate statistical techniques. For the sample characterization, the data were synthesized in the descriptive analysis of the behavior of the variables by calculating descriptive statistics (mean, median, minimum, maximum, standard deviation, coefficient of variation, interest proportions), graphs, distributions of simple frequencies and in cross tables. The Chi-square test of association was performed to verify the association between mechanical restraint and the studied variables, and the Fisher's exact test was used when appropriate and the Chi-square test was inconclusive.

In the Inferential Analysis of Quantitative Variables, the normal distribution hypothesis was verified by the KolmogorovSmirnov and Shapiro-Wilk tests. When the normal distribution hypothesis was not rejected in the groups, a comparison of two independent groups by a quantitative variable was done by the Student's t-test. The equality of the variances, which is necessary to perform the Student's t-test without correction, was evaluated by the Levene test. When the normal distribution hypothesis was rejected for any of the groups, the comparison of the two groups was done by the non-parametric Mann-Whitney test. ANOVA was used in the comparison of more than two independent groups if normality of the distribution or the Kruskal-Wallis test was confirmed. The post hoc analysis was provided by the Student Newman Keuls test. All discussions were carried out considering the maximum significance level of 5\% (0.05), meaning that the following decision rule was adopted in the tests: rejection of the null hypothesis whenever the $\mathrm{p}$-value associated to the test was less than 0.05 .

\section{ETHICAL ASPECTS}

The study was approved by the Research Ethics Committee under Opinion no. 2.172.275 on July 13 $3^{\text {th }} / 2017$, and followed the precepts of Resolution no. 466/12, of the National Health Council.

\section{RESULTS}

Fifty-seven (57) of the 111 evaluated patients were mechanically restrained. From these data, it is estimated that the prevalence of mechanical restraint of inpatients is $51.4 \%$. Among the surveyed sectors, the prevalence of restraint was $93.3 \%$ in the intensive care unit, $50.9 \%$ in the medical clinic, and $3.8 \%$ in the surgical clinic. The characterization of the mechanical restraint was also performed by means of the restraint type variables and justification for restraint, as presented in Table 1.

Table 1 - Characterization frequency distributions of mechanical restraint in the hospital environment - Niterói, RJ, Brazil, 2017.

\begin{tabular}{lcc}
\hline Restraint characteristics & $\mathbf{f}$ & $(\%)$ \\
\hline Type of restraint & & \\
Lateral rails on the bed & 40 & 70.2 \\
Lateral rails and wrist restraints & 17 & 29.8 \\
\hline Justification for restraint & & \\
Agitation & 7 & 19.3 \\
Use of Invasive Devices & 33 & 57.9 \\
Risk of falls & 57 & 100.0 \\
Other reasons & 1 & 1.8 \\
\hline
\end{tabular}

The most prevalent type of mechanical restraint were the lateral rails on the bed (100.0\% of the cases), and the patients' wrists were also restrained in $29.8 \%$ of cases. The most common reason for restraint was the risk of falls (100.0\%) and the use of invasive devices (57.9\%).

This study also characterized the restrained and unrestrained patients in order to determine the variables that showed association with the mechanical restraint. As shown in Table 2 , in the overall analysis the patients in the hospital environment had an age range of 58 to 78 years $(54.0 \%)$, was admitted to the medical clinic (49.5\%), surgical clinic (23.4\%), or intensive care unit (27.0\%), had peripheral venous catheter (64.9\%), urinary catheter (33.3\%) or used sedative medication (35.1\%).

Regarding gender, there was a predominance of males $(64.9 \%)$ in the restrained patients. The patient percentages in the hospitalization units were also significantly different in the two groups: in the group of restrained patients, the percentage of ICU patients was $49.1 \%$, as well as $1.8 \%$ of the patients were restrained in the medical and surgical clinics. Thus, restraint was significantly associated with the hospitalization place. Among the evaluated comorbidities, only stroke was significantly associated with restraint. The 
percentage of patients with stroke was significantly higher $(26.3 \%)$ in the restrained group of patients.

Patients' conditions such as ambulation capacity, use of sedative medication and mechanical ventilation were significantly different in both groups ( $\mathrm{p}$-values $=0.000$ ), meaning that they were significantly higher in the group of restrained patients. The frequencies of invasive device use for nasoenteric tube, urinary catheter, central venous catheter and orotracheal tube were significantly different in both groups.

Table 3 shows the distribution of the number of professionals per bed in each group. A higher proportion of low ratio values in the group of unrestrained patients is observed and a higher proportion of high ratio values in the restrained group. The chi-square test indicates a significant difference between the two groups ( $p$-value $=0.000$ ).

Table 4 presents an analysis of factors associated with the use of mechanical restraint in the hospital setting. These are: male, hospitalized in ICU, having been affected by stroke, not walking, using antipsychotic or sedative medication, being on mechanical ventilation and having invasive devices such as nasoenteric tube, urinary catheter, central venous catheter and orotracheal tube.

Table 2 - Frequency distribution of patients unrestrained, restrained and overall - Niterói, RJ, Brazil, 2017.

\begin{tabular}{|c|c|c|c|c|c|c|c|}
\hline \multirow[t]{2}{*}{ Variable } & \multicolumn{2}{|c|}{$\begin{array}{c}\text { Unrestrained } \\
n=54\end{array}$} & \multicolumn{2}{|c|}{$\begin{array}{c}\text { Restrained } \\
n=57\end{array}$} & \multicolumn{2}{|c|}{$\begin{array}{c}\text { Overall } \\
n=111\end{array}$} & \multirow{2}{*}{ p-Value } \\
\hline & $\mathbf{F}$ & $\%$ & $\mathbf{F}$ & $\%$ & $\mathbf{F}$ & $\%$ & \\
\hline \multicolumn{8}{|l|}{ Gender } \\
\hline Female & 33 & 61.1 & 20 & 35.1 & 53 & 47.7 & \multirow{2}{*}{0.006} \\
\hline Male & 21 & 38.9 & 37 & 64.9 & 58 & 52.3 & \\
\hline \multicolumn{8}{|l|}{ Age (years) } \\
\hline $18 \vdash 28$ & 8 & 14.8 & 1 & 1.8 & 9 & 8.1 & \multirow{8}{*}{$0.000^{(a)}$} \\
\hline $28 \vdash 38$ & 10 & 18.5 & 1 & 1.8 & 11 & 9.9 & \\
\hline $38 \vdash 48$ & 2 & 3.7 & 5 & 8.8 & 7 & 6.3 & \\
\hline $48 \vdash 58$ & 4 & 7.4 & 5 & 8.8 & 9 & 8.1 & \\
\hline $58 \vdash 68$ & 16 & 29.6 & 17 & 29.8 & 33 & 29.7 & \\
\hline $68 \vdash 78$ & 9 & 16.7 & 18 & 31.6 & 27 & 24.3 & \\
\hline $78 \vdash 88$ & 4 & 7.4 & 9 & 15.8 & 13 & 11.7 & \\
\hline $88 \vdash 98$ & 1 & 1.9 & 1 & 1.8 & 2 & 1.8 & \\
\hline \multicolumn{8}{|l|}{ Hospitalization unit } \\
\hline Intensive Care Unit & 2 & 3.7 & 28 & 49.1 & 30 & 27.0 & \multirow{3}{*}{0.000} \\
\hline Medical clinic & 27 & 50.0 & 28 & 49.1 & 55 & 49.5 & \\
\hline Surgical clinic & 25 & 46.3 & 1 & 1.8 & 26 & 23.4 & \\
\hline \multicolumn{8}{|l|}{ Comorbidities } \\
\hline Stroke & 3 & 5.6 & 15 & 26.3 & 18 & 16.2 & 0.003 \\
\hline Neoplasm & 3 & 5.6 & 5 & 8.8 & 8 & 7.2 & $0.717^{(\mathrm{b})}$ \\
\hline Kidney disease & 4 & 7.4 & 10 & 17.5 & 14 & 12.6 & 0.108 \\
\hline Respiratory disease & 4 & 7.4 & 13 & 22.8 & 17 & 15.3 & 0.024 \\
\hline Cardiac diseases & 4 & 7.4 & 5 & 8.8 & 9 & 8.1 & $1.000^{(b)}$ \\
\hline Senile Dementia/Alzheimer's & 0 & 0.0 & 5 & 8.8 & 5 & 4.5 & $0.057^{(\mathrm{b})}$ \\
\hline Diabetes Mellitus & 4 & 7.4 & 3 & 5.3 & 7 & 6.3 & $0.712^{(\mathrm{b})}$ \\
\hline Systemic Arterial Hypertension & 1 & 1.9 & 7 & 12.3 & 8 & 7.2 & $0.061^{(\mathrm{b})}$ \\
\hline \multicolumn{8}{|l|}{ Patient conditions } \\
\hline Ambulation & 48 & 88.9 & 13 & 22.8 & 61 & 55.0 & 0.000 \\
\hline Sedative Medication & 9 & 16.7 & 30 & 52.6 & 39 & 35.1 & 0.000 \\
\hline Mechanical ventilation & 0 & 0.0 & 15 & 26.3 & 15 & 13.5 & 0.000 \\
\hline \multicolumn{8}{|l|}{ Use of invasive devices } \\
\hline Peripheral Venous Catheter & 39 & 72.2 & 33 & 57.9 & 72 & 64.9 & 0.114 \\
\hline Nasoenteric tube & 0 & 0.0 & 6 & 10.5 & 6 & 5.4 & $0.027^{(b)}$ \\
\hline Urinary Catheter & 5 & 9.3 & 32 & 56.1 & 37 & 33.3 & 0.000 \\
\hline Central Venous Catheter & 1 & 1.9 & 18 & 31.6 & 19 & 17.1 & 0.000 \\
\hline Orotracheal tube & 0 & 0.0 & 12 & 21.1 & 12 & 10.8 & 0.000 \\
\hline Tracheostomy & 1 & 1.9 & 5 & 8.8 & 6 & 5.4 & $0.207^{(b)}$ \\
\hline Gastrostomy & 0 & 0.0 & 3 & 5.3 & 3 & 2.7 & $0.244^{(b)}$ \\
\hline \multicolumn{8}{|l|}{ RAAS score } \\
\hline-4 - Combative & 0 & 0.0 & 1 & 1.8 & 1 & 0.9 & \multirow{5}{*}{0.415} \\
\hline-3 - Moderate sedation & 0 & 0.0 & 1 & 1.8 & 1 & 0.9 & \\
\hline-1 - Torpor & 0 & 0.0 & 1 & 1.8 & 1 & 0.9 & \\
\hline 0 - Alert and Calm & 54 & 100.0 & 53 & 93.0 & 107 & 96.4 & \\
\hline 1 - Restless & 0 & 0.0 & 1 & 1.8 & 1 & 0.9 & \\
\hline
\end{tabular}


Table 3 - Ratio distribution of the number of professionals per bed in each group - Niterói, RJ, Brazil, 2017.

\begin{tabular}{|c|c|c|c|c|c|c|c|}
\hline \multirow{3}{*}{ Number of professionals/bed } & \multirow{2}{*}{\multicolumn{2}{|c|}{$\begin{array}{c}\text { Unrestrained } \\
n=54\end{array}$}} & \multirow{2}{*}{\multicolumn{2}{|c|}{$\begin{array}{c}\text { Restrained } \\
n=57\end{array}$}} & \multirow{2}{*}{\multicolumn{2}{|c|}{$\begin{array}{l}\text { Overall } \\
n=111\end{array}$}} & \multirow{3}{*}{$\chi^{2}$ test $p$-value } \\
\hline & & & & & & & \\
\hline & $\mathbf{F}$ & $\%$ & $\mathbf{F}$ & $\%$ & $\mathbf{F}$ & $\%$ & \\
\hline $0.25=1$ professional for each 4 beds & 35 & 64.80 & 12 & 21.10 & 47 & 42.30 & \\
\hline $0.33=1$ professional for each 3 beds & 14 & 25.90 & 15 & 26.30 & 29 & 26.10 & \\
\hline $0.42=5$ professionals for each 12 beds & 3 & 5.60 & 2 & 3.50 & 5 & 4.50 & 0.000 \\
\hline $0.5=1$ professional for each 2 beds & 0 & 0.00 & 2 & 3.50 & 2 & 1.80 & \\
\hline $0.67=2$ professionals for each 3 beds & 2 & 3.70 & 26 & 45.60 & 28 & 25.20 & \\
\hline
\end{tabular}

Table 4 - Factors associated with mechanical restraint in the hospital environment - Niterói, RJ, Brazil, 2017.

\begin{tabular}{|c|c|c|c|c|c|c|c|}
\hline \multirow[t]{2}{*}{ Factor } & \multicolumn{2}{|c|}{$\begin{array}{l}\text { Prevalence of restraint when } \\
\text { factor is NOT present }\end{array}$} & \multicolumn{2}{|c|}{$\begin{array}{c}\text { Prevalence of restraint when } \\
\text { factor IS present }\end{array}$} & \multirow{2}{*}{$\chi^{2}$ test $p$-value } & \multirow[t]{2}{*}{ OR } & \multirow[t]{2}{*}{$\mathrm{Cl}$ of the $\mathrm{OR}$} \\
\hline & $\mathbf{F}$ & $\%$ & $\mathbf{F}$ & $\%$ & & & \\
\hline Male & $20 / 53$ & 37.70 & $37 / 58$ & 63.80 & 0.006 & 2.9 & $1.3-6.3$ \\
\hline Intensive Care Unit & $30 / 82$ & 36.60 & $27 / 29$ & 93.10 & 0 & 23.4 & $5.2-105.4$ \\
\hline Stroke & $42 / 93$ & 45.20 & $15 / 18$ & 83.30 & 0.003 & 6.1 & $1.7-22.4$ \\
\hline Ambulation & $44 / 50$ & 88.00 & $13 / 61$ & 21.30 & 0 & 0.037 & $0.01-0.11$ \\
\hline Sedative Medication & $27 / 72$ & 37.50 & $30 / 39$ & 76.90 & 0 & 5.6 & $2.3-13.5$ \\
\hline Mechanical Ventilation & $42 / 96$ & 43.80 & $15 / 15$ & 100.00 & 0 & nc & $\mathrm{Nc}$ \\
\hline Nasoenteric tube & $51 / 105$ & 48.60 & 06/06 & 100.00 & $0.027^{(b)}$ & nc & $\mathrm{Nc}$ \\
\hline Urinary catheter & $25 / 74$ & 33.80 & $32 / 37$ & 86.50 & 0 & 12.5 & $4.4-36.2$ \\
\hline Orotracheal tube & $45 / 99$ & 45.50 & $12 / 12$ & 100.00 & 0 & nc & $\mathrm{Nc}$ \\
\hline
\end{tabular}

The prevalence of mechanical restraint among men is significantly higher $(63.8 \%)$, the odds ratio $(\mathrm{OR})$ is 2.9 and is significant given its confidence interval (1.3; 6.3). It is estimated that the chance of a male patient being restrained in a hospital environment is 2.9 times greater than the chance of a female patient.

The prevalence of mechanical restraint in clinical and surgical patients is $36.6 \%$, while the prevalence in the ICU is significantly higher (93.1\%). The odds ratio (OR) is equal to 23.4 and is significant given its confidence interval (5.2; 105.4). It is estimated that the chance of an ICU patient being restrained in hospital care is 23.4 times greater than the chance of a non-ICU patient.

Patient restraint due to stroke and non-ambulation is related to the greater dependence to perform activities of daily living, and the use of sedative medication is also associated with mechanical restraint. The prevalence of mechanical restraint among stroke patients who do not walk and who use antipsychotic or sedative medication is $83.3 \%, 88.0 \%$ and $76.9 \%$, respectively. It is estimated that the chance of a patient having a stroke to be restrained is 6.1 times greater than the chance of a patient who does not have a stroke. Patients who do not walk are 27 times more likely to be restrained, and this chance increases 5.6 times for those who use antipsychotic or sedative medication.

The prevalence of mechanical restraint among patients who are on mechanical ventilation, using orotracheal tube or nasoenteric tube is $100.0 \%$. The use of urinary catheter and central venous catheter were also significantly associated, with a prevalence of $86.5 \%$ and $94.7 \%$, respectively, among restrained patients.

\section{DISCUSSION}

Mechanical restraint was present in half of the evaluated patients in the investigated hospital environment, a fact that deserves attention and intervention actions by the nursing and multiprofessional teams. This prevalence was determined by the profile of patients hospitalized in the medical clinic and ICU. The prevalence of mechanical restraint in previous studies varied according to the hospitalization sectors surveyed, being from 0 to $31.3 \%$ in general care clinics and 0 to $90 \%$ in intensive care units ${ }^{(10)}$, which corroborates the findings of this study. The hospitalization sectors were also related to the mechanical restraint with the use of lateral rails. Studies which exclusively considered the lateral rails in the bed found prevalence of up to $65.7 \%$ of hospitalized adult patients ${ }^{(11)}$.

The use of bilateral bed rails which cannot be easily removed by the patient should only be indicated in exceptional and specific circumstances such as transport procedures, periods of anesthetic recovery or in situations where there is patient sedation. In principle, the use should not be indicated for patients with cognitive impairment or mental confusion, and who may have sufficient strength and agility to scale the bars or engage in accidents in attempting to handle these devices. In addition, rails are not indicated for independent patients who have preserved mental and 
cognitive status and who do not need the aid of a rail as a support element to move in the bed ${ }^{(12)}$.

When side rails are used properly regarding the design model and the precise circumstance, they can contribute to both patient protection and safety, as well as provide comfort or support for mobilization or transfer maneuvers. In such cases, rails are not considered as mechanical restraints. However, when used improperly, the rails limit and restrict the patient's freedom and mobility which can generate additional risks to their health and loss of autonomy.

Bilateral rails are not appropriate for patients with dementia, in a state of mental confusion or who have psychomotor agitation ${ }^{(13)}$. A patient who is determined to leave their bed cannot always assess the risks involved. They may attempt to climb over the rail, through lateral openings or those located near the foot of the bed. All these movements can be done in an uncoordinated or accelerated way, not infrequently resulting in accidents which involve bruises, getting stuck, asphyxia, falls or serious traumatic injuries with fatal evolution ${ }^{(1)}$.

The decision to use the rails as a safety measure should be made by a trained health professional with knowledge, skill and experience to perform the patient's risk assessment. In addition, the use of lateral rails does not replace the need for adequate observation and follow-up by the nursing team ${ }^{(12)}$.

The main justifications of the nursing team for performing restraint identified in this study refer to a perception of fall risk and the use of invasive devices. A case-control study related the risk of falling with the patients' profile and the use of medication. As a result, it has been identified that bed falls in hospitals has a multifactorial etiology, suggesting that variations in the clinical health status and mental health of the patient increase this risk. Among the mentioned aspects are: gait problems or lack of strength in the lower limbs; frequency of physiological eliminations; urinary incontinence; confusion; and use of antipsychotic or sedative medication ${ }^{(14)}$.

Therefore, the characteristics of the restrained patients identified in this study such as not walking and the use of sedative medication are related to the increased risk of falling and apparently would justify the use of lateral rails as a safety measure. However, there is not consistent scientific support so far in the literature.

The use of rails as a measure to restrict the freedom of movement ends up leading to immobility and insulation, resulting in a vicious cycle of consequences. Thus, both its clinical indication and its function as supportive care or a preventive device are questioned. Direct human care cannot be replaced by using rails, nor the need for patient monitoring and care, as well as assistance in a rehabilitation program. Without proper individualized evaluation of patients to decide whether or not to use bilateral rails in the hospital bed, this may be an attitude that leads to new risks of adverse events instead of characterizing a protective measure. Therefore, its use if not indicated departs from the precepts that characterize a preventive, therapeutic or care action.

Another commonly found justification was the use of invasive devices, mainly in the intensive care unit, in which there is greater use of them for the maintenance and recovery of patients' health. The team performs mechanical restraint with the intention of protecting the patient, avoiding an abrupt withdrawal of invasive devices which can cause lesions and treatment discontinuity. Moreover, according to the literature there is concern about the equipment and devices that are being used in the patient because they increase the costs for the institution when they are damaged ${ }^{(15)}$. However, the use of mechanical restraints paradoxically increases the risk of pressure injury, friction injury, psychomotor agitation, immobility, aggressiveness, in addition to the ethical and legal precepts involved ${ }^{(4,10,16-17)}$.

The ratio of nursing professionals per bed was evaluated and was shown to be higher among restrained patients. This finding may be related to the fact that the nursing team was significantly larger in the intensive care unit, where there was a higher prevalence of restrained patients. The medical and surgical clinics had a reduced number of professionals, and although it was high in the medical clinic, the prevalence in the surgical clinic was low. It is worth mentioning that during the observations, the daily nurse reported as the chief advised that patients should engage in early ambulation accompanied by the staff and family who were allowed to accompany them in the postoperative period, and then lowered the rails. Therefore, it can be stated that the reduced number of professionals in the team was not related to the higher frequency of mechanical restraint, confirming another study in which a lower proportion of nurses per hospitalized patient was not associated with a higher prevalence of mechanical restraint ${ }^{(16)}$.

Age above 58 years was one of the factors associated with the use of mechanical restraint. This result is related to the increasing number of older adults hospitalized in hospitals, especially in the Intensive Care Unit (ICU). "Population aging increases the frequency of older patients with health problems requiring ICU treatment, since the incidence of chronic degenerative diseases increases with advancing age" ${ }^{\text {(17) }}$.

Among the group of restrained patients, one of the highlights was the majority being male, which may be related to evidence observed in other studies conducted in Brazil, pointing out that men seek treatment later and are hospitalized in more severe health conditions ${ }^{(18)}$. It can be hypothesized that male hospitalizations are mainly due to mental disorders, injuries due to external causes and circulatory diseases, increasing the chances of using drugs and invasive devices used for treatment; factors which may contribute to the greater probability of psychomotor agitation. It can also be inferred that men have a muscular and strength biotype that may cause fear to a female nursing team, but possibly other qualitative study designs are needed to deepen power relations and gender in the use of mechanical restraint in hospital settings.

Regarding the patients' hospitalization time, it was identified that the restrained patients had more hospitalization days when compared to those unrestrained. The general health status, motor and cognitive capacity of patients and the use of mechanical restraint can significantly affect length of hospital stay ${ }^{(19)}$. Concomitant adverse 
effects related to mechanical restraint such as a feeling of impotence, restless behavior and postponing patient mobilization in the bed may also contribute to an increase in hospital stay length ${ }^{(4)}$.

Regarding the evaluation of the evidence of agitation and sedation by the Richmond scale, mechanical restraint was not significantly associated since almost all evaluated patients were alert and calm. This result is in contrast to other findings, in which the use of mechanical restraint was associated with delirium, coma, sedative or psychoactive patients, and inability to communicate verbally ${ }^{(11,20)}$; a finding that merits more particular reflection since it points to the possibility of routine and less critical use of mechanical restraint.

Therefore, this research ratifies that the main reason for implementing mechanical restraints in a hospital environment is related to the intention to prevent falls or the withdrawal of biomedical devices. Through this result and with support from normative documents and those of scientific ethical nature ${ }^{(2,4-5,10)}$ which put this conduct into question, the issue that arises is whether mechanical restraint is an adequate intervention for preventing these risks. The fact that the literature points out that restraint aggravates the patient's mental confusion and agitation, and consequently the will to self-withdraw from devices, to move freely or to get up, associates the restraint with triggering various injuries which include the risk of fatal events ${ }^{(2,4,10)}$. This implies adverse events being associated with hospitalization and professional attitude, and deserves to be reflected upon. Another consideration is the fact that the restraint affects the patient's emotional state which can become astonished, apathetic, dysthymic and not resistant to the fact that they remain restrained for 24 hours, revealing a possible attitude of withdrawal or resignation.

Therefore, it can be said that mechanical restraint carried out in an empirical way and exempt from clinical evaluation may cause risks. Professionals believe that they are ensuring patient safety in performing restraint, but when performed improperly it can result in severe clinical consequences to patients, such as impairment to cognitive status, motor agitation, pressure injuries, increased length of hospital stay and depersonalization of nursing care.

Mechanical restraint must be characterized by exceptionality, following strict technical and ethical criteria, and when necessary should be assisted, limited to the control of complex clinical situations, dialogued, described in the medical record, accompanied, and suspended as soon as possible. Planning and executing mechanical restraint in the hospital environment requires investigation into the cause of restraint, and a restraint management team can be idealized to do this, specializing in the care and resolution of complex cases, with measures to prevent a scenario of uninterrupted and inappropriate restraint.

\section{CONCLUSION}

This study estimates a high prevalence of mechanical restraint in the studied hospital environment, with the use of lateral rails in the bed as the main form, and associated to the patients' wrists also being restrained. The main reasons for restraint were the risk of falls and the use of invasive devices. The patient's age, the male gender, the hospitalization unit, the capacity for walking, the use of invasive devices and sedative medication were identified as factors which were associated to using mechanical restraint.

\section{RESUMO}

Objetivo: Estimar a prevalência de contenção mecânica no ambiente hospitalar e os fatores associados à sua realização. Método: Estudo transversal, observacional, com pacientes provenientes de um hospital público, dos setores de clínica médica, clínica cirúrgica e unidade de terapia intensiva, analisados de modo descritivo, uni e multivariado. Resultados: Participaram do estudo 111 pacientes. A prevalência de contenção mecânica foi de 51,4\%; em 100\% dos contidos foram utilizadas grades bilaterais no leito, e em 29,8\% observou-se também a contenção bilateral dos pulsos. As justificativas mais comuns foram o risco de quedas $(100,0 \%)$ e o risco de retirada não programada de dispositivos invasivos (57,9\%). Os pacientes contidos diferem-se significativamente dos não contidos pelos seguintes fatores associados: sexo masculino; idade; diagnóstico de Acidente Vascular Encefálico; à unidade de internação; à capacidade de deambulação; ao uso de medicação sedativa e ao uso de dispositivos invasivos. Conclusão: Este estudo estimou uma alta prevalência da contenção mecânica no ambiente hospitalar e determinou fatores associados ao risco de um paciente ser contido. Recomenda-se um time de avaliação da contenção para análise aprofundada da indicação e terapêutica.

\section{DESCRITORES}

Restrição Física; Assistência Hospitalar; Cuidados de Enfermagem; Humanização da Assistência; Segurança do Paciente.

\section{RESUMEN}

Objetivo: Estimar la prevalencia de contención mecánica en el entorno hospitalario y los factores asociados con su realización. Método: Estudio transversal, observacional, con pacientes provenientes de un hospital público, de los sectores de clínica médica, clínica quirúrgica y unidad de cuidados intensivos, analizados de modo descriptivo, uni y multivariado. Resultados: Participaron en el estudio 111 pacientes. La prevalencia de contención mecánica fue del 51,4\%; en el 100\% de los contenidos se utilizaron rejas bilaterales en el lecho, y en el 29,8\% se observó también la contención bilateral de las muñecas. Las justificaciones más comunes fueron el riesgo de caídas $(100,0 \%)$ y el riesgo de retiradas no programadas de dispositivos invasivos $(57,9 \%)$. Los pacientes contenidos se difieren significativamente de los no contenidos por los siguientes factores asociados: sexo masculino; edad; diagnóstico de Accidente Vascular Encefálico; a la unidad de estancia hospitalaria; a la capacidad de deambulación; al uso de medicación sedativa y al uso de dispositivos invasivos. Conclusión: Este estudio estimó una alta prevalencia de la contención mecánica en el entorno hospitalario y determinó los factores asociados con el riesgo de contenerse a un paciente. Se recomienda a un equipo de evaluación de la contención para análisis profundizado de la indicación y terapéutica.

\section{DESCRIPTORES}

Restricción Física; Atención Hospitalaria; Atención de Enfermería; Humanización de la Atención; Seguridad del Paciente. 


\section{REFERENCES}

1. Potter PA, Perry AG. Fundamentos de enfermagem. $8^{\text {a }}$ ed. Rio de Janeiro: Elsevier; 2012.

2. Menezes AK, Santana RF, Cimador F. Práticas assistenciais restritivas e o paradigma da cultura de não contenção da pessoa idosa. In: Tratado de geriatria e gerontologia. $4^{\mathrm{a}}$ ed. Rio de Janeiro: Guanabara Koogan; 2016. p. 6582-627.

3. Bleijlevens $M H$, Wagner LM, Capezuti E, Hamers JP. Physical restraints: consensus of a research definition using a modified Delphi Technique. J Am Geriatr Soc. 2016;64(11):2307-10. DOI: 10.1111/jgs.14435

4. Berzlanovich AM, Shöpfer J, Keil W. Deaths due to physical restraint. Dtsch Arztebl Int [Internet]. 2012 [cited 2017 Oct 28];109(3):27-32. Available from: https://www.ncbi.nlm.nih.gov/pmc/articles/PMC3272587/

5. Conselho Federal de Enfermagem. Resolução n. 427, de 8 de maio de 2012. Normatiza os procedimentos da Enfermagem no emprego de contenção mecânica de pacientes [Internet]. Brasília; 2012 [citado 2017 out. 25]. Disponível em: http://www.cofen.gov.br/resoluocofen-n-4272012_9146.html

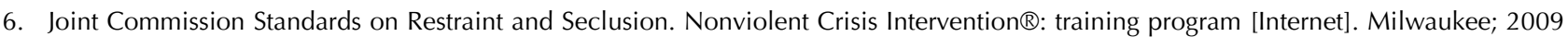
[cited 2017 Oct 25]. Available from: https://www.crisisprevention.com/CPI/media/Media/Resources/alignments/Joint-CommissionRestraint-Seclusion-Alignment-2011.pdf

7. Sessler CN, Gosnell M, Grap MJ, Brophy GT, O'neal PV, Keane KA. The Richmond Agitation-Sedation Scale: validity and reliability in adult intensive care patients. Am J Respir Crit Care Med. 2002;166(10):1338-44. DOI: 10.1164/rccm.2107138

8. Lourenço RA, Veras RP. Mini-Mental State Examination: psychometric characteristics in elderly outpatients. Rev Saúde Pública [Internet]. 2006 [cited 2017 Nov 03];40(4):712-9. Available from: http://www.scielo.br/scielo.php?script=sci_arttext\&pid=S0034$89102006000500023 \& \operatorname{lng}=\mathrm{en} \& \mathrm{nrm}=\mathrm{iso} \& \operatorname{lng}=\mathrm{en}$

9. Katz S, Ford AB, Moskowitz RW, Jackson BA, Jaffe MW. Studies of illness in the aged. The index of ADL: a standardized measure of biological and psychosocial function. JAMA. 1963;185:914-9. DOI: http://dx.doi.org/10.1590/S0034-89102006000500023

10. Krüger C, Mayer H, Haastert B, Meyer G. Use of physical restraints in acute hospitals in Germany: a multi-centre cross-sectional study. Int J Nurs Stud. 2013;50(12):1599-606. DOI: http://dx.doi.org/10.1016/j.ijnurstu.2013.05.005.

11. Oearsakul B, Sirapo-Ngam Y, Strumpf NE, Malathum P. Physical restraint use among hospitalized elderly Thais. Pacific Rim Int J Nurs Res. 2011;15(2):125-36.

12. NHS Foundation Trust. Protocol for the safe effective use of bedrails [Internet]. London; 2017 [cited 2018 Jan 12]. Available from: https:// www.nhft.nhs.uk/download.cfm?doc=docm93jijm4n1859.pdf\&ver=9038

13. Healey F, Oliver D, Milne A, Connelly JB. The effect of bedrails on falls and injury: a systematic review of clinical studies. Age Ageing. 2008;37(4):368-78. DOI: http://dx.doi.org/10.1093/ageing/afn112.

14. Krauss MJ, Evanoff B, Hitcho E, Ngugi KE, Dunagan WC, Fischer I, et al. A case-control study of patient, medication, and care-related risk factors for inpatient falls. J Gen Intern Med. 2005;20(2):116-22. DOI: http://dx.doi.org/10.1111/j.1525-1497.2005.40171.x

15. Minnick AF, Mion LC, Johnson ME, Catrambone C, Leipzig R. Prevalence and variation of physical restraint use in acute care settings in the US. J Nurs Scholarsh. 2007;39(1):30-7.

16. Heinze C, Dassen T, Grittner U. Use of physical restraints in nursing homes and hospitals and related factors: a cross-sectional study. J Clin Nurs. 2012;21(7):1033-40. DOI: http://dx.doi.org/10.1111/j.1365-2702.2011.03931.x

17. Rodriguez AH, Bub MBC, Perão OF, Zandonadi G, Rodriguez MJH. Epidemiological characteristics and causes of deaths in hospitalized patients under intensive care. Rev Bras Enferm [Internet]. 2016 [cited 2017 Nov 20];69(2):210-4. Available from: http://www.scielo.br/ scielo.php?script=sci_arttext\&pid=S0034-71672016000200229. DOI: http://dx.doi.org/10.1590/0034-7167.2016690204i

18. Arruda GO, Molena-Fernandes CA, Mathias TAF, Marcon SS. Hospital morbidity in a medium-sized city: differentials between men and women. Rev Latino Am Enfermagem [Internet]. 2014 [cited 2017 Nov 26];22(1):19-27. Available from: http://www.scielo.br/scielo. php?script=sci_arttext\&pid=S0104-11692014000100019

19. Bai X, Kwok TCY, Ip IN, Woo J, Chui MYP, Ho FKY. Physical restraint use and older patients' length of hospital stay. Health Psychol Behav Med. 2014;2(1):160-70. DOI: http://dx.doi.org/ 10.1080/21642850.2014.881258

20. Kooi AW, Peelen LM, Raijmakers RJ, Vroegop RL, Bakker DF, Tekatli H, et al. Use of physical restraints in Dutch intensive care units: a prospective multicenter study. Am J Crit Care. 2015;24(6):488-95. DOI: http://dx.doi.org/ 10.4037/ajcc2015348 